\title{
Multicultural Value In New York And Samawi Novels of Damien Dematra
}

\author{
${ }^{1}$ Wawan Hermawan, ${ }^{2}$ Suyitno, ${ }^{3}$ Herman J. Waluyo, ${ }^{4}$ Nugraheni Eko Wardhani \\ wawanhermawanunim@gmail.com \\ 1,2,3,4 Sebelas Maret University
}

\begin{abstract}
This study aims to describe the multicultural values contained in the New York and Samawi novels by Damien Dematra. This type of research is qualitative research with the sociological approach to literature. The data of this research are written data derived from objective data, namely the New York and Samawi novels by Damien Dematra. Data analysis techniques use content analysis techniques. Data validation in this study is triangulation theory. Research results show that the multicultural values contained in the New York and Samawi novels by Damien Dematra include: appreciation of the reality of cultural plurality in society, recognition of human dignity and human rights, development of world community responsibility, and development of human responsibility against planet earth.
\end{abstract}

Keywords: multicultural, value, and novels.

\section{Introduction}

Multiculturalism is a characteristic of the attitude of the Indonesian people which is reflected in the behavior of every citizen who respects the existence of a religious, ethnic and cultural difference. The differences in religion, ethnicity and culture that exist in Indonesia are seen as a multicultural society. This statement is in line with the view of Taufik[1] which states that a society will be called a multicultural society if in a society two or more cultural lives and they respect, respect and tolerate one another. But in reality awareness of the sensitivity to the multicultural reality, pluralism, and pluralism of the nation both ethnic, cultural and religious is still low in tolerance. These problems can be seen from the lack of harmony between groups, ethnic groups and religions in building a conducive atmosphere. This is in line with the views of Syaifudin[2], which states that awareness (and pride) of shared identity as a nation, and shared historical awareness and shared destiny, especially among younger generations now and in the future experiencing a decline.

This kind of multicultural phenomenon is not just posed as merely socio-cultural understanding. Rather, it is already at the application stage in everyday life. This is because multiculturalism becomes the wealth and strength of the nation in maintaining and unifying ethnic, cultural and religious diversity in Indonesia. To maintain and unite these diversity, it needs comprehensive, earnest and consistent efforts from various parties. These efforts include applying multicultural literature studies. The implementation of multicultural phenomenology can be seen in multicultural literature studies. The statement is in line with the opinion of Taufik[1] which states that multiculturalism in literary work is a study in the field of literature that is very interesting, because Indonesian literary works, especially novels are one type of Indonesian literary work that can reflect various multicultural phenomena that occur in society, both past and present.

Multicultural literature studies have an important role in building and formulating solutions for the benefit of the nation and state, because multicultural literature has a close 
relationship with social, cultural, ideological, political and identity issues. This is in line with the view of Darma (2004: 2) which states that socio-cultural problems including dynamic cultural relations and the emergence of identity problems are central themes in the study of multicultural literature. The statement was emphasized by Susanto[3] which revealed that literary works are cultural products and as a cultural product literary works reflect or represent the reality of the surrounding community and in its time. The focus of the study in this study is the multicultural values in the New York and Samawi novels by Damien Dematra with the perspective of sociology of literary works. The sociology of work approach is one approach in analyzing a literary work by looking at a text from the socio-cultural community contained in the novel. This is in line with the views of Wellek and Warren[4] sociology of literary works to blame the content of literary works, goals, and other things implied in the literary work itself and relating to social problems.

Interest and reason researchers chose Damien Dematra as the object of research studies because Damien Dematra is a multitalented person, both a novelist, director, producer, photographer and painter. As a novelist, Damien Dematra has written 101 novels and books in Indonesian and English. As a director has produced 81 screenplays of films and TV series. As a photographer, Damien Dematra obtained two of the highest photographer titles, namely: Fellowship in the field of Portraiture and Art Phofotography from Master Photographer, in addition to being awarded the International Master Photographer of the Year, and WPPI Grand Award winner. As a painter, Damien Dematra has produced thousands of paintings and sketches, including 365 paintings completed within a year. In addition, Damien Dematra currently has 13 world records, including as the fastest writer in the world, the fastest published novel writer in the world, the fastest photographer in the world, the world's thickest book writer, the fastest filmmaker in the world from the primier deep scenario 9 days 17 hours and 45 minutes, etc. In addition, Damien Dematra is active as coordinator of the National Pluralism Concern Movement (GPP) and chairman of the National Writing Movement (GNM). Damien Dematra's track record that has been explained is the basis of the interest and confidence of researchers to research Damien Dematra's works. Damien's novels that are interesting to study are New York and Samawi novels. The reason for choosing these novels as research studies is that the New York and Samawi novels are very interesting in terms of themes. The themes in the novel under study reflect the problem of tolerance and multiculturalism, namely: religious, ethnic and cultural diversity.

The New York novel tells of the friendship of three sincere and innocent children who are divine (religions born of the descendants of the prophet Ibrahim). The three children are: Zakaria, Yavis, and Anthony. Zakaria is a Muslim child of an Indonesian diplomat who followed his father to New York in 1973 who was seven years old. His house in Mornigside Heights was opposite Yavin's house, a Jewish child of the same age as Zakaria. When attending school he met Anthony, a Catholic, a child of a wealthy merchant from Indonesia. Almost every day Anthony went to church, while Zakaria learned to recite diligently and Yavin tried to carry out the commandments in the Torah. Everyday is filled with solid friendship and curiosity about each other's religions. However, the friendships that have been established for years began to deter after growing up and knowing the meaning of love. The next novel that was examined was the Samawi novel by Damien. The Samawi novel tells the story of three friends of celestial religions (religions of the descendants of the prophet Ibrahim) who fought in their respective faiths facing disasters, surpassed suffering, and sought hope that there was still a split of peace between the sharp points of difference.

Previous research discussing muticulture in the novel's focus is: ethnicity, culture, and soiocultural. The discussion of multicultural values and the sociological perspective of 
literary works in the novel has not been carried out by previous researchers. This is the novelty of this research, because both the focus of study, theory, and the method studied have not been carried out together in the previous research.

\section{Literature Review}

Parekh[5] views multiculturalism as a philosophy that is also sometimes interpreted as an ideology that requires the union of various cultural groups with the same rights and social status in modern society. Parekh[5] further categorizes the concept of multiculturalism into three main parts. First, the difference in subculture (subculture divesity), namely individuals or groups of people who live with different perspectives and habits with large communities with a value or cultural system that applies in general. Second, perspective differences (perspectival diversity) are individuals or groups with a critical perspective on the value mainstream or established culture adopted by the majority of the surrounding community. Third, communal diversity, namely individuals or groups who live with a genuine lifestyle in accordance with their communal identity (indigeneous people way of life).

Another view of multiculturalism expressed by Mudzhar[6], which states multiculturalism is a term used to explain one's view of the diversity of life in the world, or cultural policies that emphasize the acceptance of the reality of diversity, and the various types of culture (multicultural) that exist in people's lives concerning the values, systems, culture, habits and politics that they profess. In line with previous views, Tilaar[7] defines multiculturalism as an acknowledgment of cultural plurality. Agreeing with Tilaar's view, Wahid[8] explained that multiculturalism is a concept of a community's recognition of diversity, diversity and cultural differences, both ethnicity, race, ethnicity, religion, and so on. In line with this view, Mahfud[9] reveals that multicultural means the understanding of diversity (plural) of culture (adat) which is owned by a group of communities. Furthermore, Mahfud[9] explains that multiculturalism is an understanding that emphasizes equality and equality of local cultures without ignoring the existing cultural rights. The essence of multiculturalism is equality.

Based on the views of several experts on the nature of multiculturalism, it can be synthesized that multiculturalism is recognition and acceptance of the existence of a diversity of cultures, ethnicities, and religions that are in the midst of society.

Tilaar[7] revealed that there are four core values of multicultural education, namely an appreciation of the reality of cultural plurality in society, the recognition of human dignity and human rights, the development of world community responsibility, and the development of human responsibility towards planet earth . In addition, Maslikhah[10] revealed that multicultural education has an orientation, namely: humanity, togetherness, welfare, proportionality, plurality and heterogeneity, and anti-hegemony and domination. The following is an explanation of the six orientations of multicultural education.

First is humanity orientation. Humanity or humanism is a natural value that becomes the foundation and goal of education. Humanity is global, universal above all tribes, schools, races, groups and religions. These humanistic values illustrate the belief in the greatness of God, the wise and respectful treatment of him, build the spirit to be loyal to others, and treat nature as it treats and places itself. Multicultural education with a humanitarian orientation is expected to be human who fully animates humanistic values without losing their identity Maslikhah[10], Second is togetherness orientation. Togetherness or cooperativesme is a very noble value in realizing the ideals of multicultural education in a pluralistic and heterogeneous society. Togetherness that is built is togetherness that does not harm others, the environment, 
and yourself. Education that is built with togetherness is able to become a quantum for peaceful education Maslikhah[10].

Third is welfare orientation. Welfare is a social condition that is everyone's hope. Welfare so far has only been used as an empty slogan. Multicultural education orientation on prosperity does not mean that you have to be stuck with excessive material fulfillment and as much as other people, but to make the community aware and not feel forced or say that today has felt a prosperous life Maslikhah[10]. The fourth is proportional orientation. Proportion in the orientation of multicultural education is a value that is viewed from any aspect as very appropriate. Accuracy here is not interpreted as rigrid accuracy in the sense of only using one consideration, for example intellectual consideration, or quantity, but accuracy in terms of all dimensions. Multicultural education in order to build education foundation proportionally by prioritizing appreciation for plurality, heterogeneity and humanity Maslikhah[10].

Fifth is plurality orientation and heterogeneity. Plurality and heterogeneity is a reality that cannot be suppressed fascistly by raising an attitude of fanaticism towards a truth that is believed by a group of people. Educational orientations that instill values accept opinions, thoughts, policy theories, education systems, economic, social, and political policies in accordance with multicultural education Maslikhah[10]. The sixth is the orientation of antihegemony and domination. Anti-hegemony and domination in multicultural education can make multicultural education more coherent. Multicultural education that is anti-hegemony and domination can build education that promotes plurality values for humanity, welfare, and justice proportionally in its policies Maslikhah[10].

From several views on multicultural values it can be stated that in this study researchers used four core values of multicultural education as expressed by Tilaar, namely appreciation of the reality of cultural plurality in society, recognition of human values and human rights, development of responsibility the world community, and the development of human responsibility towards planet earth.

Wellek and Warren[4] make a classification about the perspective of literary sociology, which is the basis of the researcher to analyze literary works in this study. There are three classifications of literary sociology, namely: author sociology, work sociology and reader sociology. The focus of the study in this study is sociology rich in literature. The sociology of literary work disputes the literary work itself, the subject of the study is what is implied in the literary work and what is its purpose. The contents of literary works related to social problems, in this case are often seen as social documents, or as portraits of social reality Wellek and Warren[4]. Furthermore Wellek and Warren[4], reveal that as a social document, literature must be understood as a protret of social reality that arises from literary works, or the work is intended as a realistic picture, or is a satire, caricature, or romantic idealism.

Research conducted by researchers has relevance to previous research, namely multicultural. Relevant research describing multiculturalism was carried out by, Mermann[11] entitled Beyond Multiculturalism: Ethnic Studies, Transnationalism, and Junot Díaz's Oscar Wao, Sazyek[12] with the title Phases of Multicultural Progress at The Novels of Elif Safak, Toshimenla[13] with title of Multiculturalism in Kiran Desai's The Inheritance of Loss, Suroso[14] with the title Multiculturalism in Indonesian Novels As a Culture-Uniting Device, Singh[15] entitled Construction of Identity and Multiculturalism in Novels: Asemiotic and Psychoanalytic Study of '2States' by Chetan Bhagat, Kaviyarasu[16] with the title Postcolonial Multicultural Identity in Rudyard Kipling's Kim. All previous studies that discussed muticultural use the novel as the object of study, while the aspects studied were: ethnicity, culture and culture. The discussion of multicultural values and the sociological perspective of literary works in the novel has not been carried out by researchers beforehand together in the 
research. This has become a novelty of research, because both the focus of study, theory, and the method studied have not been carried out together in the previous research

\section{Material \& Methodogy}

\subsection{Data}

This research data is written data in the form of documents. This document data comes from objective data. The objective data in this study came from the novel New York, and Samawi was rich in Damien Dematra which contained multicultural values both in terms of character depiction and dialogue between characters.

\subsection{Method}

This type of research is qualitative research. Moleong[17] states that qualitative research is research that intends to understand the phenomena experienced by research subjects. This study uses a sociological approach to literature. These data are data on the multicultural values of civil society in the New York and Samawi novels by Damien Dematra.

\subsection{Teknik Analisis Data}

Data analysis techniques in this study use content analysis techniques. Content analysis is a research method used to determine the conclusions of a text (Weber[18].

Furthermore, Krippendroff[19] defines content analysis as "a research technique for making replicable and valid inference from texts (or other meaningful matter) to the contexts of their use.

\subsection{Validation Data}

Data validity testing in qualitative research includes several tests. Researchers used the theory triangulation test. Trianggulation is defined as checking data from various sources in various ways and at various times. Trianggulation technique according to Sutopo[20] consists of four types, namely triangulation of sources, methods, researchers, and theory. Source triangulation is done by checking the data obtained from several sources. Triangulation theory is using several theories so that the findings obtained are valid. The theory that is the reference to validate the findings in this study is the theory of the literary sociology of Wellek and Warren.

\section{Results and Discussion}

4.1 Result

Data validity testing in qualitative research includes several tests. Researchers used the theory triangulation test. Trianggulation is defined as checking data from various sources in various ways and at various times. Trianggulation technique according to Sutopo[20] consists of four types, namely triangulation of sources, methods, researchers, and theory. Source triangulation is done by checking the data obtained from several sources. Triangulation theory is using several theories so that the findings obtained are valid. The theory that is the reference to validate the findings in this study is the theory of the literary sociology of Wellek and Warren.

4.1.1 Appreciation of the plurality of cultures in societyThe first multicultural values are appreciation of the plurality of cultures in society. This value is contained in the New York and Samawi novels by Damien Dematra. This can be seen in the quote below: 
"Yang penting sekarang, apapun keyakinan kita, kamu harus bisa bergaul dengan orang lain. Mereka semua umat ciptaan Allah." (43/New York).

The quotation above shows the existence of multicultural values which refers to an appreciation of the existence of a plurality of cultures in society. This can be seen from the recognition that respects existing religious differences. The next quote on the same novel also shows an appreciation of the plurality of cultures in society. As follows.

"Penghuni daerah itu didominasi oleh orang-orang Puetro Rico, Italia, dan Africa American." (9/new york).

The quote above shows that there is an appreciation of the cultural differences that exist in society. This was shown from the inhabitants of the area of his residence which was dominated from various countries and even continents, which showed the existence of cultural differences in the community. The value of appreciation for the existence of a plurality of cultures in society is not only found in New York novels but also in Samawi's novels. Can be seen in the quote below.

"Ya, itulah. Kalian gak mungkin jadi Kristen. Yang Kristen tetep Kristen, yang Islam tetep Islam, yang Budha tetp Budha, yang Konghucu tetep Konghucu. (129/Samawi).

Excerpts in the Samawi novel above show a plurality. This can be seen from the statement which states that despite adopting a different religion, it still becomes and believes in the religion it adheres to. Subsequent quotes are also consistent with

"Menurut saya Kristen dan Islam malah dapat bergandengan tangan. Saya memiliki sahabat Islam, sekalipun saya sudah tidak pernah bertemu dengannya lagi, dan waktu bersahabat, saya merasa bahwa saya rela mati untuk melinduninya. Sahabat tidak berarti menjadi sama seperti dia, namun merima mereka apa adanya dan membiarkan mereka menjadi diri mereka.(130/Samawi).

The quote above shows the existence of plurality in society. The plurality in the quotation is shown from the differences in religion adopted by friends, not to be a problem, instead making the protector of fellow protectors.

4.1.2 Recognition of human dignity and human rights

The second multicultural value relates to the recognition of human dignity and human rights. These values are shown in the quotation below.

"Ya supaya Islam memiliki hak yang sam di Amerika, karena kita minoritas di sini.."(78/Samawi).

The quote above shows the value of recognition of human dignity and human rights. This value is seen from the statement contained in the quote stating that Islam has the same rights as America. This is confirmed by the following quote, namely:

"Bahwa setiap manusia memiliki hak yang sama, dan dalam hal ini, aku berbicara untuk Islam di Amerika"(92/Samawi).

Recognition of human dignity and human rights in the above quote is shown from the disclosure of the same rights of Islam and America, there is no minority even though Islam is in America.

4.1.3 Development of the responsibility of the world community

The development of the responsibility of the world community is the third value in the analysis of multicultural values. This value is reflected in the two novels by Damien Dematra. Following is the quote of the value.

"Oh iya! Mungkin aku sumbangin aja, ya, lewat Anthony? Dia kan suka ngurusi begituan." (102/New York). 
The quote above shows the responsibility of the world community. This value is shown by the feeling of empathy among fellow human beings perceived by Zakaria, so he donates a portion of his clothes through Anthony. Subsequent quotes also show the same thing with regard to the responsibilities of the world community even in different novels.

Gadis itu aktif membantu orang-orang miskin di Afrika, Vietnam, dan Amerika Latin.(125/Samawi).

The quote from Samawi's novel shows the responsibility of the world community. This is reflected in the activities of a girl who actively helps poor people in various countries and even continents.

4.1.4 Development of human responsibility for planet earth

The last value of multiculturalism is human responsibility towards planet earth. This value is contained in the New York and Samawi novels. Following below is the quote of the value.

“Kalau begitu, aku akan ikut Papa aja. Menjadi pendamai." (37/New York).

The quote above shows that there is a human responsibility towards planet earth. This responsibility is shown by the desire to be peace on earth, so that there are no more names of violence, intimidation and war. Evidence of human responsibility for planet earth is reflected in Samawi's novel. The following is the quote below.

Ia, Anthony, Yavin, dan Kenned, telah mendaftarkan diri untuk turut membantu dalam aksi sosial membantu lingkungan. (16/Samawi).

The quote from Samawi's novel shows that there is a human responsibility for planet earth. This was indicated by his statement that participated in helping the environment.

\subsection{Discussion}

Based on the results of the study found multicultural values in the New York and Samawi novels by Damien Dematra. These values are an appreciation of the reality of cultural plurality in society, the recognition of human dignity and human rights, the development of the responsibilities of the world community, and the development of human responsibility for planet earth. The findings agree with Tilaar's (2004: 210) view which reveals that there are four core values of multicultural education, namely an appreciation of the reality of cultural plurality in society, recognition of human dignity and human rights, development of world community responsibility, and developing human responsibility for planet earth.

Multicultural values found in the novel by Damien Dematra show the existence of a diversity of religions, cultures that exist in multicultural societies. These findings are in line with Wahid[8] opinion that multiculturalism is a concept of a community's recognition of diversity, diversity and cultural differences, both ethnicity, race, ethnicity, religion, and so on. This is confirmed from the view of Mahfud[9] expressing multicultural means understanding diversity (plural) of culture (adat) which is owned by a group of communities. The multicultural values contained in the New York and Samawi novels are reflected in the dialogue between the characters and the depiction of characters.

\section{Conclusion}

Dari hasil penelitian dan pembahasan dapat disimpulkan bahwa nilai-nilai multikultural yang terdapat dalam novel New York dan Samawi karya Damien Dematra meliputi apresiasi terhadap adanya kenyataan pluralitas budaya dalam masyarakat, pengakuan terhadap harkat manusia dan hak asasi manusia, pengembangan tanggung jawab masyarakat dunia, dan 
pengembangan tanggung jawab manusia terhadap planet bumi. Nilai-nilai multikultural dapat terlihat dari penggambaran tokoh maupun dialog antartokoh.

From the results of the research and discussion it can be concluded that the multicultural values contained in the New York and Samawi novels by Damien Dematra include an appreciation of the reality of cultural plurality in society, recognition of human dignity and human rights, development of world community responsibility, and development human responsibility for planet earth. Multicultural values can be seen from the depiction of characters and dialogue between characters.

\section{References}

[1] A. Taufik, Sastra Multikultural, Konstruksi Ideologi Kebangsaan dalam Novel Indonesia. Surabaya: Pascasarjana Unesa, 2014.

[2] A. F. Syaifuddin, "Membumikan Multikulturalisme di Indonesia," ETNOVISI J. Antropol. Sos. Budaya, vol. 11, no. 1, pp. 3-11, 2006.

[3] D. Susanto, Pengantar Teori Sastra. Yogyakarta: Caps, 2012.

[4] R. \& A. W. Wellek, Teori Kesusastraan. Jakarta, 2016.

[5] B. Parekh, Rethinking Multiculturalism, Keberagaman Budaya dan Teori Politik. Jakarta: Kanisius, 2008.

[6] M. A. Mudzhar, Pengembangan Masyarakat Multikultural Indonesia danTantangan ke depan (Tinjauan dari aspek Keagamaan dalam Meretas Wawasan \& Praksis Kerukunan Umat Beragama di Indonesia. Jakarta: Badan Litbang dan Diklat Keagamaan Puslitbang Kehidupan Beragama Depag RI, 2005.

[7] H. A. . Tilaar, Multikulturalisme Tantangan-Tantangan Global Masa Depan dalam Transformasi Pendidikan Nasional. Jakarta: Grasindo, 2004.

[8] A. Wahid, Pergulatan Negara, Agama, dan Kebudayaan. Depok: Desantra, 2001.

[9] C. Mahfud, Pendidikan Multikultural. Yogyakarta: Pustaka Pelajar, 2009.

[10] Maslikhah, Quo Vadis Pendidikan Multikultural: Rekonstruksi Sistem Pendidikan Berbasis Kebangsaan. Surabaya: JP Books kerjasama dengan STAIN Salatiga Press, 2007.

[11] E. M. and J. Mermann, "Beyond Multiculturalism: Ethnic Studies,Transnationalism, and Junot Díaz's Oscar Wao," Ariel a Rev. Int. english Lit., vol. 43, no. 2, pp. 1-24, 2013.

[12] E. Sazyek, "Phases of Multicultural Progress at The Novels of Elif Şafak," Int. Period. Lang. Lit. Hist. Turkish or Turkic, vol. 8, no. 4, pp. 1221-1242, 2013.

[13] Toshimenla and N.D.R. Chandra, "Multiculturalism in Kiran Desai's," Inherit. Loss. J. Lit. Cult. Media Stud., vol. 9, no. 10, pp. 88-93, 2013.

[14] Suroso, "Multiculturalism in Indonesian Novels As a Culture-Uniting Device," J. Soc. Sci., vol. 5, no. 22, pp. 130-135, 2014.

[15] G. R. K. Singh, "Construction of Identity and Multiculturalism in Novels: Asemiotic and Psychoanalytic Study of '2States' by Chetan Bhagat," Int. J. Manag. Humanit. Soc. Sci., vol. 1, no. 1, pp. 1-18, 2016.

[16] k. S. R. Kaviyarasu, "Post-colonial Multicultural Identity in Rudyard Kipling's Kim," An Int. Ref. English e-Journal, vol. 2, no. 4, pp. 244-248, 2017.

[17] lexy Moeleong, Metodelogi Penelitian Kualitatif. Bandung: Remaja Rusdakarya, 2013.

[18] R. P. Weber, Basic Content Analysis. California: Sage Publication, 1990.

[19] K. Krippendorff, Content Analysis: An Introductions to its Methodology, Second Edi. 
California: Sage Publication, 2004.

[20] Sutopo. H. B, Metodologi Penelitian Kualitatif: Dasar Teori dan Terapannya dalam Penelitian. Surakarta: Universitas Sebelas Maret Press, 2006. 